\title{
THE APPLICATION OF MULTI-CRITERIA ANALYSIS IN THE EVALUATION OF PARTERING RELATIONS AND THE SELECTION OF A CONSTRUCTION COMPANY FOR THE PURPOSES OF COOPERATION
}

\section{E. RADZISZEWSKA-ZIELINA ${ }^{1}$}

\begin{abstract}
The influence that general contractors and subcontractors have on the operation of a company is immense. Keeping this in mind, the authors have decided to develop and algorithm based on the analysis of partnering relations between construction companies that would select the best possible construction company for the purposes of cooperation. This algorithm, developed for a given construction company, is meant to support its decision-making system in the field of the selection of another construction company to cooperate with. The author has made references to earlier research, in which she had used the ELECTRE III method, and in which she had analysed the possibility of applying the BIPOLAR method in order to solve the problem of the selection of a construction company to develop partnering relations with. The author provided an example of the calculations performed for a selection of construction companies.
\end{abstract}

Keywords: construction company, multi-criteria analysis, partnering relations

\section{INTRODUCTION}

The Construction Industry Institute has proposed a definition of partnership in its report for the year 1991, titled "In The Search For A Perfect Partnership" [2], describing it as a long-term commitment by two or more organisations to achieve specific business goals by attaining the maximum possible effectiveness of the resources of each participant. This relationship is based on trust, a commitment

\footnotetext{
${ }^{1}$ Assoc. Prof., PhD., Eng., Cracow University of Technology, Institute of Management in Construction and Transport, Warszawska Street 24, 31-155 Cracow, Poland, Poland, e-mail: eradzisz@izwbit.pk.edu.pl
} 
to common goals and the understanding of mutual, individual expectations and values. The expected benefits include an increase in effectiveness, a decrease in costs, a rise in the amount of opportunities for innovation and a continuous improvement of the quality of products and services. Partnership, in contrast to competition, can be described as cooperation instead of rivalry. Partners cooperate with each other by carrying out a construction project, which is their common goal, as well as in order to achieve mutual benefits [13].

Subcontractors and general contractors have an important influence on the functioning of a construction company. It is due to this fact that the author decided to develop an algorithm that would select the best possible construction company to cooperate with, based on an analysis of partnering relations between construction companies. This algorithm, developed for a particular construction company, is meant to support its decision-making system in the capacity to select another construction company for the purposes of entering a partnership. A detailed analysis of the publications on the subject of partnership has been provided by the author in [21]. The author developed and published [20] a research model of the analysis of partnering relations, as well as an original algorithm that utilises the ELECTRE III method and that can be used in the process of the selection of a construction company to enter a partnership with. The author has also provided calculations involving a case of seven construction companies.

There are numerous publications on the subject of the methods of evaluating and selecting contractors, which are seen as an important element in the organisation and management of engineering and construction projects. For instance, paper [24] provides a method of ranking contractors, while paper [25] illustrates the analysis of the selection of subcontractors performed by Turkish contractors working on international construction projects. Article [7] details the use of the AHP method to evaluate the criteria of selecting a contractor for a construction project. The discourse contained in these publications is biased towards the investor (and not a construction company), without focusing solely on the context of building long-lasting, partnering relations, which is the focus of the author $[17,18,19,20,22]$.

The methods that utilise multi-criteria analysis are useful in solving decision problems in Construction Project Engineering [4,6]. Some authors prefer the fuzzy approach to using a multicriteria analysis of decision problems [11]. There are numerous books on the subject of multi-criteriabased methods, for instance $[3,8,14,16]$. The most popular and the most widely used method is AHP [12]. This method was used in the selection of the manner of the construction of a bridge [15], the selection of a contractor [7], to evaluate partnering relations in the construction industry [1], as well as to analyse the risk associated with the adaptation of abandoned public buildings [5]. The use of the 
BIPOLAR method is considerably less widespread [9, 10, 23]. There is no subject literature that features a similar implementation of multi-criteria methods in the process of selecting the best possible construction company to form partnering relations with, to the one that has been presented by the author.

The evaluation of the problem by using methods that feature multi-criteria analysis should be performed with the use of at least two different methods due to the imperfections. There exists a way to verify both the methods themselves and the results that have been obtained. This is why the article is going to focus on the problem of the evaluation of partnering relations and the selection of a construction company to cooperate with, which had already been analysed using the ELECTRE III method in paper [20], and which is going to be analysed using the BIPOLAR method. The aim of the author is to verify earlier research using an alternative method.

\section{AN EXAMPLE OF THE FUNCTIONING OF AN METHOD BASED ON THE BIPOLAR APPROACH}

\subsection{THE APPLICATION OF THE BIPOLAR METHOD}

The main advantage of using the BIPOLAR method in the case of the example that has been provided, is the ability to obtain three types of rankings. The selection of a decision variant (a construction company to cooperate with) on the basis of a type S ranking offers the maximum degree of achieving success. The selection of a construction company to cooperate with on the basis of a type $\mathrm{N}$ ranking minimises the degree of failure. The B type ranking combines both the degree of achieving success, as well as the degree of avoiding failure. When selecting a construction company to cooperate with based on a type $\mathrm{S}$ ranking, we do not take into account the degree of failure. This can result in the selection of variants with a substantial risk of failure, which can be interpreted in the context of partnering relations as difficulties in the ability to build said relations with the selected company. When using an $\mathrm{N}$ type ranking to select a construction company, we can minimise the degree of failure. This means that establishing partnering relations with such a company is almost certain, however, they can be low-level relations. The B type ranking combines both of the advantages of these rankings. This approach utilises both the degree of achieving success and that of avoiding failure while establishing a ranking of construction companies. In the case of partnering relations, the result is the selection of a construction company that has a relatively high probability of establishing 
partnering relations with, while said relations can be of a considerably high level. Decision-makers can base their decisions on the ranking which they believe is the most appropriate in a given situation. Another benefit of using this method is the ability to define the preferences of the decision-maker on the basis of pointing out both positive and negative reference objects, which translates into the possibility of pointing to examples of construction companies that are acceptable or unacceptable to the decision-maker. This manner of introducing a decision-maker's preferences into the system makes it possible to construct a self-learning system (which learns from the preferences of the decisionmaker). Such a system can independently modify its reference lists regarding acceptable or unacceptable objects on the basis of subsequent tasks (earlier cases of construction projects) that the decision-maker used it for, including the decision-maker's previous choices (the construction companies which were selected to carry out earlier construction projects). The reference objects do not need to be actual companies - they can be objects created for the purposes of a particular analysis. "The BIPOLAR method is a method of multi-criteria decision-making support, used to sort and rank a finite number of decision variants. The comparison between the decision variants is not performed in a direct manner, but with the use of a bipolar reference system, which contains both "good" and "bad" objects [23, p. 56]

The method is comprised of three phases:

- the comparison of the decision variants with elements of the reference system, the establishment of outranking indicators and the definition of the preference structure,

- the determination of the position of each decision variant in relation to the bipolar reference system,

- drawing conclusions on the basis of the relations in a set of the decision variants that are being analysed, based on the results obtained during previous phases.

\subsection{EXAMPLE OF CALCULATIONS}

The author provided a set of decision variants - the same construction companies that had been analysed using the ELECTRE III method. The evaluations of the companies, as well as the initial data for the 7 companies are the same as in the aforementioned example [20].

The rows of the table provided below (table 1) show information regarding each of the seven companies, while the columns contain the evaluation criteria (14 parameters). The higher grades for each parameter of relation are preferred over the lower grades. 
Table 1. Evaluation of construction companies

\begin{tabular}{|c|c|c|c|c|c|c|c|c|c|c|c|c|c|c|}
\hline \multirow{2}{*}{$\begin{array}{l}\text { Companies } \\
\text { (decision } \\
\text { variants) }\end{array}$} & \multicolumn{14}{|c|}{$\begin{array}{l}\text { The level (grade) of the relationship between a construction company and the } \\
\text { contractor/subcontractor due to specific parameters (evaluation criteria) }\end{array}$} \\
\hline & $f_{1}$ & $\mathrm{f}_{2}$ & $\mathrm{f}_{3}$ & $\mathrm{f}_{4}$ & $\mathrm{f}_{5}$ & $\mathrm{f}_{6}$ & $f_{7}$ & $\mathrm{f}_{8}$ & $f_{9}$ & $f_{10}$ & $\mathrm{f}_{11}$ & $f_{12}$ & $f_{13}$ & $\mathrm{f}_{14}$ \\
\hline $\mathrm{a}^{1}$ & 5 & 4 & 5 & 4 & 5 & 5 & 1 & 2 & 5 & 2 & 4 & 3 & 4 & 5 \\
\hline$a^{2}$ & 5 & 5 & 3 & 2 & 3 & 2 & 1 & 1 & 2 & 2 & 3 & 3 & 2 & 3 \\
\hline$a^{3}$ & 4 & 3 & 4 & 3 & 5 & 5 & 5 & 5 & 5 & 4 & 4 & 5 & 4 & 5 \\
\hline $\mathrm{a}^{4}$ & 3 & 3 & 3 & 3 & 3 & 3 & 1 & 2 & 3 & 3 & 3 & 3 & 4 & 3 \\
\hline$a^{5}$ & 3 & 4 & 4 & 3 & 5 & 2 & 4 & 5 & 3 & 4 & 4 & 4 & 3 & 4 \\
\hline$a^{6}$ & 5 & 5 & 1 & 5 & 1 & 5 & 5 & 5 & 5 & 5 & 5 & 5 & 5 & 3 \\
\hline$a^{7}$ & 5 & 5 & 4 & 5 & 4 & 2 & 1 & 3 & 5 & 5 & 5 & 5 & 5 & 5 \\
\hline
\end{tabular}

The importance of each criterion - relationship parameter - was provided by experts on a scale of 15. The evaluation of each parameter, based on the opinions of 147 experts from construction companies based in the Małopolskie Voivodship, have been averaged and normalised [21]. The weights that have thus been obtained, ranging from $w_{1}$ to $w_{14}$ (equivalent to each of the evaluation criteria) meet the requirements below:

$$
\sum_{k=1}^{14} w_{k}=1 \quad w_{k} \geq 0
$$

In a manner analogous to the ELECTRE III method, a $q_{k}$ equivalence threshold was defined for each criterion. In the case of the ELECTRE III method, equivalence thresholds take on the form of functions, while in the BIPOLAR method they are numbers. The thresholds which were represented by stable functions in the case of the ELECTRE III method are represented by a $q_{k}$ equivalence threshold of the same value. In the case of equivalence thresholds that were represented by functions, the BIPOLAR method values were established in a manner which would provide the highest possible compatibility. The veto threshold plays a different role in the BIPOLAR method to the one that it plays in the ELECTRE III method. In the ELECTRE III method, the veto threshold allows for a quick rejection of decision variants, while in the BIPOLAR method it can be used as an aid in the establishment of tests regarding the possibility of conflict. The veto threshold $v_{k}$ was established as equal to zero, so that the tests regarding the possibility of conflict could take into account all of the criteria. The assumed equivalence and veto thresholds, as well the weights of each parameter, have been provided in table 2 . 
Table 2. The assumed equivalence and veto thresholds and parameter weights

\begin{tabular}{|c|c|c|c|}
\hline Parameters & $\begin{array}{l}\text { Equivalence } \\
\text { thresholds } q_{k}\end{array}$ & $\begin{array}{c}\text { Veto thresholds } \\
v_{k}\end{array}$ & $\begin{array}{c}\text { Weights } \\
w_{k}\end{array}$ \\
\hline$f_{1}$ The basis of making an order & 1 & 0 & 0,075 \\
\hline$f_{2}$ Number of suppliers & 1 & 0 & 0,067 \\
\hline $\begin{array}{c}f_{3} \text { Approach to quality assurance } \\
\text { control }\end{array}$ & 0 & 0 & 0,056 \\
\hline$f_{4}$ Division of costs & 1 & 0 & 0,083 \\
\hline$f_{5}$ Adaptation to shifts in the market & 0 & 0 & 0,083 \\
\hline $\begin{array}{c}f_{6} \text { Participation in a new bid by the } \\
\text { company }\end{array}$ & 0 & 0 & 0,050 \\
\hline$f_{7}$ Mutual relations & 0 & 0 & 0,042 \\
\hline$f_{8}$ Method of communication & 1 & 0 & 0,058 \\
\hline$f_{9}$ Information sharing & 1 & 0 & 0,075 \\
\hline$f_{10}$ Resolution of conflicts & 0 & 0 & 0,086 \\
\hline$f_{11}$ Standards, rules of conduct & 0 & 0 & 0,083 \\
\hline$f_{12}$ Frequency of contact & 0 & 0 & 0,081 \\
\hline$f_{13}$ Approach to quality & 1 & 0 & 0,086 \\
\hline$f_{14}$ Trust & 0 & 0 & 0,072 \\
\hline
\end{tabular}

The criteria $f_{1}, f_{2}, f_{4}, f_{8}, f_{9}, f_{13}$ have had the value of their equivalence threshold set to 1 , with the other criteria having a value of 0 . All of the criteria have had their veto thresholds set to 0 . In addition, the BIPOLAR method features a minimum compatibility level of $s$ criterion grades in the form of an outranking threshold. The outranking threshold needs to meet the condition of $0 \leq s \leq 1$. The author assumed an outranking threshold equal to 0,6 . When the value of the outranking threshold is higher than 0,5 , it causes the process of defining the preference structure not to yield incomparable elements (or it yields a very small number of them). The value of the outranking threshold is picked by the user in accordance with their individual preferences. The analysis that has been conducted below was done with an outranking threshold value of 0,6. An important element of the BIPOLAR method is the process of defining the reference system. This system is composed of a set of decision variants "good" and "bad" construction companies, in accordance with the formula:

$$
\mathrm{R}=D \cup Z
$$

where:

$\mathrm{D}$ - is a set of good companies, $\mathrm{Z}$ - is a set of bad companies, $\mathrm{R}$ - is a set of reference companies.

The authors conducted their analysis based on the reference system in table 3 . 
Table 3. The reference system forming the base of the analysis

\begin{tabular}{|c|c|c|c|c|c|}
\hline \multirow{2}{*}{ Parameters } & \multicolumn{3}{|c|}{ "good" company grades } & \multicolumn{2}{c|}{ "bad" company grades } \\
\cline { 2 - 6 } & $a^{8}$ & $a^{9}$ & $a^{10}$ & $a^{11}$ & $a^{12}$ \\
\hline$f_{1}$ & 4 & 4 & 4 & 3 & 3 \\
\hline$f_{2}$ & 5 & 5 & 5 & 3 & 3 \\
\hline$f_{3}$ & 4 & 4 & 4 & 3 & 4 \\
\hline$f_{4}$ & 4 & 4 & 4 & 3 & 4 \\
\hline$f_{5}$ & 4 & 3 & 3 & 3 & 4 \\
\hline$f_{6}$ & 4 & 3 & 3 & 3 & 4 \\
\hline$f_{7}$ & 4 & 4 & 4 & 3 & 4 \\
\hline$f_{8}$ & 4 & 4 & 4 & 3 & 2 \\
\hline$f_{9}$ & 4 & 4 & 4 & 3 & 2 \\
\hline$f_{10}$ & 4 & 4 & 4 & 3 & 2 \\
\hline$f_{11}$ & 4 & 3 & 3 & 3 & 4 \\
\hline$f_{12}$ & 5 & 5 & 4 & 3 & 3 \\
\hline$f_{13}$ & 5 & 5 & 4 & 3 & 3 \\
\hline$f_{14}$ & 5 & 5 & 5 & 3 & 3 \\
\hline
\end{tabular}

The first stage of the BIPOLAR method entails the calculation of outranking indicators $d^{+}\left(a^{i}, r^{j}\right), d^{t}$ $\left(a^{i}, r^{j}\right)$, where $a^{i}$ - is a company belonging to a decision variant set, and $r^{j}$ - is a company belonging to the reference system (good or bad). The formulas used in order to obtain the value of outranking indicators are contained in the book by Trzaskalik [23, p. 57-59]. The author of the method is Korzeniewska-Gubała $[9,10]$.

The results of the calculations used to determine the values of outranking indicators for companies included in the reference system have been provided in table 4 and table 5 .

Table 4. Outranking indicators $d^{+}\left(a^{i}, r^{j}\right)$ for companies included in the reference system

\begin{tabular}{|c|c|c|c|c|c|}
\hline Companies & $a^{8}$ & $a^{9}$ & $a^{10}$ & $a^{11}$ & $a^{12}$ \\
\hline$a^{1}$ & 0 & 0,732 & 0,732 & 0,871 & 0,958 \\
\hline$a^{2}$ & 0 & 0 & 0 & 0 & 0 \\
\hline$a^{3}$ & 0,933 & 0,933 & 0,933 & 1 & 1 \\
\hline$a^{4}$ & 0 & 0 & 0 & 0 & 0 \\
\hline$a^{5}$ & 0 & 0 & 0,877 & 0,949 & 0,949 \\
\hline$a^{6}$ & 0,788 & 0,788 & 0,788 & 0,860 & 0,860 \\
\hline$a^{7}$ & 0,908 & 0,908 & 0,908 & 0,908 & 0,908 \\
\hline
\end{tabular}

Table 5. Outranking indicators $d^{t}\left(a^{i}, r^{j}\right)$ for companies included in the reference system

\begin{tabular}{|c|c|c|c|c|c|}
\hline Companies & $a^{8}$ & $a^{9}$ & $a^{10}$ & $a^{I I}$ & $a^{12}$ \\
\hline$a^{1}$ & 0,810 & 0 & 0 & 0 & 0 \\
\hline$a^{2}$ & 1 & 1 & 1 & 0,858 & 0,858 \\
\hline$a^{3}$ & 0 & 0 & 0 & 0 & 0 \\
\hline$a^{4}$ & 1 & 1 & 1 & 1 & 0,914 \\
\hline$a^{5}$ & 0,916 & 0,833 & 0 & 0 & 0 \\
\hline$a^{6}$ & 0 & 0 & 0 & 0 & 0 \\
\hline$a^{7}$ & 0 & 0 & 0 & 0 & 0 \\
\hline
\end{tabular}


The next step is the establishment of the preference structure. By using the previously calculated outranking indicators, we can define one of the three relations for each pair of objects: broad preference $(L)$, equivalence $(I)$ and indistinguishability $(R)$.

$$
\begin{aligned}
& a^{i} L r^{j}, \text { provided that } d^{+}\left(a^{i}, r^{j}\right)>s \wedge d^{+}\left(a^{i}, r^{j}\right)=0, \\
& r^{j} L a^{i} \text {, provided that } d^{+}\left(a^{i}, r^{j}\right)=0 \wedge d^{+}\left(a^{i}, r^{j}\right)>s \\
& a^{i} I r^{j}, \text { provided that } d^{+}\left(a^{i}, r^{j}\right)>s \wedge d^{t}\left(a^{i}, r^{j}\right)>s \\
& a^{i} R r^{j} \text { for the remaining cases. }
\end{aligned}
$$

\begin{tabular}{|c|c|c|c|c|c|}
\hline Companies & $a^{8}$ & $a^{9}$ & $a^{10}$ & $a^{l l}$ & $a^{12}$ \\
\hline$a^{1}$ & $a^{8} L a^{1}$ & $a^{l} L a^{9}$ & $a^{1} L a^{10}$ & $a^{l} L r^{11}$ & $a^{l} L^{12}$ \\
\hline$a^{2}$ & $a^{8} L a^{2}$ & $a^{9} L a^{2}$ & $a^{10} L a^{2}$ & $a^{11} L a^{2}$ & $a^{12} L a^{2}$ \\
\hline$a^{3}$ & $\overline{a^{3} L a^{8}}$ & $a^{3} L a^{9}$ & $a^{3} \mathrm{La}^{10}$ & $a^{3} L a^{11}$ & $a^{3} L a^{12}$ \\
\hline$a^{4}$ & $a^{8} L a^{4}$ & $a^{9} L a^{4}$ & $a^{10} L a^{4}$ & $a^{11} L a^{4}$ & $a^{12} L a^{4}$ \\
\hline$a^{5}$ & $a^{8} L a^{5}$ & $a^{9} L a^{5}$ & $a^{5} \mathrm{La}^{10}$ & $a^{5} \mathrm{La}^{11}$ & $a^{5} \mathrm{La}^{12}$ \\
\hline$a^{6}$ & $\overline{a^{6} \mathrm{La}^{8}}$ & $a^{6}{L a^{9}}^{9}$ & $a^{6} \mathrm{La}^{10}$ & $a^{6} L a^{11}$ & $a^{6} L a^{12}$ \\
\hline$a^{7}$ & $\overline{a^{7} \mathrm{La}^{8}}$ & $a^{7} \mathrm{La}^{9}$ & $a^{7} \mathrm{La}^{10}$ & $a^{7} L a^{11}$ & $a^{7} \mathrm{La}^{12}$ \\
\hline
\end{tabular}

Table 6 presents the preference structure defined for the purposes of this paper.

Table 6. Preference structure.

The next stage involves the establishment of the position of each of the construction companies by comparing them with other "good" D companies and "bad" Z companies.

A degree of the achievement of success $\mathrm{d}_{i S}$ and a degree of the avoidance of failure $d_{i N}$. has been calculated for all companies (failure is equal to selecting a company which we do not have good relations with and the construction project is not going to succeed). The values of $d_{i s}$ (which are equal to $d_{i D}{ }^{+}, d_{i D^{-}}$or 0 , in accordance with the formulas provided below), and $d_{i N}$ (which are equal to $d_{i Z^{-}}$, $d_{i Z}{ }^{+}$or 0$)$ are used to sort and establish order among the variants.

$$
d_{i s}=\left\{\begin{array}{l}
d_{i D}^{+}=\max \left\{d^{+}\left(a^{i}, d^{h}\right): a^{i} L d^{h} v a^{i} I d^{h}\right\}, \text { provided that }\left\{h: a^{i} L d^{h} v a^{i} I d^{h}\right\}, \text { when } \neq 0, \\
d_{i D}^{-}=\min \left\{d^{-}\left(a^{i}, d^{h}\right): d^{h} L a^{i}\right\}, \text { provided that }\left\{h: a^{i} L d^{h} v a^{i} I d^{h}\right\}=0 \wedge\left\{h: d^{h} L a^{i}\right\} \neq 0 \\
0 \text { in other cases }
\end{array}\right\}
$$

$$
d_{i N}=\left\{\begin{array}{l}
d_{i Z}^{-}=\max \left\{d^{-}\left(a^{i}, z^{h}\right): z^{h} L a^{i} \vee z^{h} I a^{i}\right\}, \text { provided that }\left\{h: z^{h} L a^{i} \vee z^{h} I a^{i}\right\}, \text { when } \neq 0, \\
d_{i Z}^{+}=\min \left\{d^{+}\left(a^{i}, z^{h}\right): a^{i} L z^{h}\right\}, \text { provided that }\left\{h: z^{h} L a^{i} \vee z^{h} L a^{i}\right\} \neq 0 \wedge\left\{h: a^{i} L z^{h} \neq 0,\right. \\
0 \text { in other cases. }
\end{array}\right\}
$$


Table 7. The position of decision variants - construction companies - in relation to the reference system

\begin{tabular}{|c|c|c|c|c|}
\hline Companies & $d_{i S}$ & Type $d_{i S}$ & $d_{i N}$ & Type $d_{i N}$ \\
\hline$a^{1}$ & 0,732 & 1 & 0,872 & 1 \\
\hline$a^{2}$ & 1 & -1 & 0,858 & -1 \\
\hline$a^{3}$ & 0,933 & 1 & 1 & 1 \\
\hline$a^{4}$ & 1 & -1 & 1 & -1 \\
\hline$a^{5}$ & 0,877 & 1 & 0,950 & 1 \\
\hline$a^{6}$ & 0,788 & 1 & 0,861 & 1 \\
\hline$a^{7}$ & 0,908 & 1 & 0,908 & 1 \\
\hline
\end{tabular}

The „Type $d_{i}$ " column (tabele 7) illustrates which formula was used to obtain the $d_{i S}$ value. A value of 1 implies that $d_{i S}=\mathrm{d}_{\mathrm{iD}}{ }^{+}$, while a value of -1 implies that $d_{i S}=\mathrm{d}_{\mathrm{iD}}{ }^{-}$. The ,Type $d_{i N}$ " column shows the formula used to calculate the $d_{i N}$ value. A value of 1 implies that $d_{i N}=\mathrm{d}_{\mathrm{iz}}{ }^{+}$, while a value of -1 implies that $d_{i N}=\mathrm{d}_{\mathrm{iZ}}$.

Based on the coefficients which describe the position of decision variant in relation to the reference system, we can order the companies based on the following criteria: the degree of the achievement of success and the degree of avoiding failure. Sorting the companies based on the degree of achieving success is performed by using the $d_{i s}$ value. There are three categories:

- $\mathrm{S} 1$ (overgood type objects - $a^{i}$ companies for which $d_{i S=} d_{i D}{ }^{+}>0$ ),

- $\mathrm{S} 2$ ( $a^{i}$ companies for which $\left.d_{i S=} d_{i D^{-}}>0\right)$,

- S3 (incomparable objects - $a^{i}$ companies for which $d_{i S=0}$ ).

The process of sorting based on the degree of avoiding failure is based on the $d_{i N}$. coefficient. The categories here are as follows:

- $\mathrm{N} 1$ (including $a^{i}$ companies for which $d_{i N=} d_{i Z}{ }^{+}>0$ ),

- $\quad \mathrm{N} 2$ (overgood type objects, including $a^{i}$ companies for which $d_{i N=} d_{i Z^{-}}>0$ ),

- $\quad \mathrm{N} 3$ (incomparable objects, $a^{i}$ companies for which $d_{i N=0}$ ).

We can see that we are provided with two rankings of companies that are under consideration. In order to obtain a cumulative evaluation for each company, we need to define three categories of objects:

- $\mathrm{B} 1$ (a category that includes $a^{i}$ companies, for which $d_{i D}{ }^{+}>0 \wedge d_{i Z}{ }^{+}>0$ ),

- $\mathrm{B} 2$ (a category that includes $a^{i}$ companies, for which $d_{i D^{-}}>0 \wedge d_{i Z}{ }^{+}>0$ ),

- $\quad$ B3 (a category that includes $a^{i}$ companies, for which $d_{i D^{-}}>0 \wedge d_{i Z^{-}}>0$ ).

We are arriving at conclusions about a set of the analysed decision variants - construction companies. 
The position of the decision variants in relation to the $d_{i s}, d_{i N}$ reference system has been determined. We have also established company rankings and categories based on the degree of achieving success $\mathrm{d}_{i S}$ (table 8, table 9)

Table 8. A ranking of category S1 companies (overgood) and their $d_{i S}$ degrees of achieving success.

\begin{tabular}{|c|c|}
\hline company & $d_{i s=d_{i D}{ }^{+}}$ \\
\hline$a^{3}$ & 0,933 \\
\hline$a^{7}$ & 0,908 \\
\hline$a^{5}$ & 0,877 \\
\hline$a^{6}$ & 0,788 \\
\hline$a^{1}$ & 0,732 \\
\hline
\end{tabular}

Table 9. A ranking of category S2 companies and their $d_{i s}$ degrees of achieving success

\begin{tabular}{|c|c|}
\hline company & $d_{i S=d_{i D^{-}}}$ \\
\hline$a^{2}$ & 1 \\
\hline$a^{4}$ & 1 \\
\hline
\end{tabular}

The analysis yielded no elements that fitted the criteria of the S3 category.

Category S1 companies are better than category S2 companies due to possessing a higher degree of the achievement of success. The companies listed in the tables are sorted based on their $d_{i S}$ degree of achieving success. The $a^{3}$ company turned out to be the best company. The $a^{7}$ company is the second best, although its degree of achieving success is lower by a value of only 0.025 in comparison to the best company. Category S1 companies have an $d_{i S}$ value ranging between 0,732 and 0,933 . Category $\mathrm{S} 2$ is comprised of only two companies, namely $a^{2}$ and $a^{4}$. The $d_{i s}$ factor for these companies has a value of 1 . This makes it impossible to discern which of these two companies is better. Category S3 contains incomparable objects and is empty in the case of this analysis. This is a consequence of the fact that the analysis was performed while taking into account a high outranking indicator value, equal to 0,6 .

The company ranking featuring the degree of the avoidance of failure $d_{i N}$ has been provided in table 10 and table 11.

Table 10. A ranking of category N1 companies and their $d_{i N}$ degrees of avoiding failure.

\begin{tabular}{|c|c|}
\hline company & $d_{i N=} d_{i Z}{ }^{+}$ \\
\hline$a^{3}$ & 1 \\
\hline$a^{5}$ & 0,950 \\
\hline$a^{7}$ & 0,908 \\
\hline$a^{1}$ & 0,872 \\
\hline$a^{6}$ & 0,861 \\
\hline
\end{tabular}


Table 11. A ranking of category N2 companies and their $d_{i N}$ degrees of avoiding failure.

\begin{tabular}{|c|c|}
\hline company & $d_{i N=d_{i Z}}$ \\
\hline$a^{4}$ & 1 \\
\hline$a^{2}$ & 0,858 \\
\hline
\end{tabular}

The analysis yielded no N3 category companies. Companies that belong to the N1 category are better than the companies belonging to the $\mathrm{N} 2$ category due to the value of the $d_{i N}$ degree of the avoidance of failure. The companies listed in the tables are sorted on the basis of the value of their $d_{i N}$ degree of the avoidance of failure. Company $a^{3}$ has been shown to be the best company. Its $d_{i N}$ value is the highest possible value of 1 . Company $a^{5}$ is the second best one, and has a value of the degree of the avoidance of failure that is lower by a value of only 0,05 in comparison to the highest value in the ranking. N1 category companies have a $d_{i N}$ value ranging between 0,861 abd 1 , The N2 category only includes two companies: $a^{4}$ and $a^{2}$. The $d_{i N}$ factor for company $a^{4}$ has the highest possible value of 1 . Category N3 contains incomparable objects. The current analysis has yielded no objects that could be included in it. This is the result of the fact the analysis was conducted with an outranking indicator of 0,6 . The company $a^{3}$ has been established to be the best one both in terms of its degree of success, as well as its degree of the avoidance of failure. It needs to be highlighted that category S1 (the category that features a ranking of the companies based on their degree of the achievement of success $d_{i S}$ ) is populated by the same companies that are included in category N1 (which features companies ranked

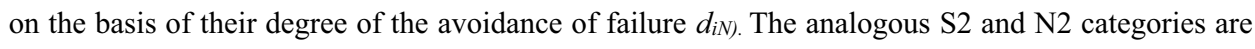
also populated with an identical set of companies.

In order to provide a full evaluation of the degree of the achievement of success and the degree of the avoidance of failure, the author has provided a ranking of companies, as well as a list of companies belonging to the three B categories (table 12, table 13).

Table12. A ranking of B1 category companies and their respective sorting factors

\begin{tabular}{|c|c|}
\hline company & $d_{i S}+d_{i N}$ \\
\hline$a^{3}$ & 1,933 \\
\hline$a^{5}$ & 1,827 \\
\hline$a^{7}$ & 1,816 \\
\hline$a^{6}$ & 1,649 \\
\hline$a^{1}$ & 1,604 \\
\hline
\end{tabular}

Table 13. A ranking of B2 category companies and their respective sorting factors

\begin{tabular}{|c|c|}
\hline company & $1-d_{i S}+d_{i N^{-}}$ \\
\hline$a^{2}$ & 1,858 \\
\hline$a^{4}$ & 2 \\
\hline
\end{tabular}


The analysis has yielded no B3 category companies. The company that tops the joint ranking is company $a^{3}$. This is confirmed by the fact that this company proved to be the best both in the ranking based on the degree of the achievement of success, as well as the ranking based on the degree of the avoidance of failure. Predictably, category B1 is populated by the same companies that are included in categories $\mathrm{S} 1$ and $\mathrm{N} 1(\mathrm{~B} 1=\mathrm{S} 1=\mathrm{N} 1)$. The same can be said of categories $\mathrm{B} 2, \mathrm{~S} 2$ and N2 $(\mathrm{B} 2=\mathrm{S} 2$ = N2). The categories of incomparable objects: B3, S3 and N3 contained no companies. The results that have been obtained are comparable to those provided by using the ELECTRE III method.

\section{CONCLUSION}

The author referenced an earlier publication, in which she had applied an ELECTRE III method algorithm in order to develop a method of selecting a construction company to establish partnering relations with for the purposes of carrying out a construction project. The author analyses the possibility of using the BIPOLAR method to solve the problem of selecting a construction company to establish partnering relations with. In order to verify the results of previous research, the author has provided an example of the calculations used in the selection of a construction company from among a group of 7 construction companies for the purposes of forming partnering relations. The construction companies in question are the same companies that had been used previous research.

The author pointed to the advantages of using the BIPOLAR method and presented an example of the calculations based on the method. The author made use of an identical set of decision variants the construction companies which were analysed - to the one that had been used previously in an example of the use of the ELECTRE III method. The evaluations and the base data for each of the 7 companies that were analysed were the same as in the case of the aforementioned example. The most appropriate company for the establishment of partnering relations with the goal of carrying out construction projects was company no. 3. The next most appropriate company was company no. 7 . The end result was the same as in the case of the analysis that had been performed using the ELECTRE III method for the same companies. The companies that were singled out as the most appropriate were the same. In the case of slight differences in the rankings, it can be assumed that they do not form a certain basis for the selection of the most appropriate company to cooperate with. The methods that have been developed are meant to support the decision-making system of a construction company in the selection of a subcontractor or another construction company for the purpose of establishing partnering relations. The final decisions must always be made by the decisionmakers themselves. 


\section{REFERENCES}

1. Chen, T.T., Wu, T.C. "Construction project partnering using fuzzy based decision making methodology", Journal of the Chinese Institute of Engineers, Vol. 35, No. 3, 2012, pp. 269-284.

2. Construction Industry Institute (CII), "In Search of Partnering Excellence, Special Publication", Report by the Partnering Task Force of CII, Austin, Texas, USA, 199.

3. Dytczak, M. „Wybrane metody rozwiązywania wielokryterialnych problemów decyzyjnych w budownictwie”. Oficyna Wydawnicza Politechniki Opolskiej, 2010.

4. Hashemi, SS., Hajiagha, SHR., Zavadskas, EK., Mandiraji, HA., „Multicriteria group decision making with ELECTRE III method based on interval-valued intuitionistic fuzzy information", Applied Mathematical Modelling, Vol. 40, No. 2, pp. 1554-1564.

5. Hsueh S-L., Lee J-R., Chen Y-L., "DFAHP Multicriteria risk assessment model for redeveloping derelict public buildings", International Journal of Strategic Property Management, Vol.17, No. 4, 2013, 333-346.

6. Ibadov N., Rosłon J., "Technology selection for construction project, with the use of fuzzy preference relation", Archives of Civil Engineering, vol. LXI, is. 3, 2015, pp. 105-118.

7. Jaśkowski P., Biruk S., Bucoń R "Assessing contractor selection criteria weights with fuzzy AHP method application in group decision environment”. Automation in Construction, Vol.19, No.2, 2010, pp. 120-126.

8. Kobryń A., „Wielokryterialne wspomaganie decyzji w gospodarowaniu przestrzenią”, Difin, 2014.

9. Korzeniewska-Gubała E. "Multiple Criteria Benchmarking using the BIPOLAR method", in: T.Trzaskalik, J.Michnik: Advances in Multiple Objective and Goal Programming, Lecture Notes in Economics and Mathematical Systems, Springer-Verlag, Berlin 2001.

10. Korzeniewska-Gubała E., "Wielokryterialne wspomaganie decyzji: system BIPOLAR", Prace Naukowe Akademii Ekonomicznej we Wrocławiu, Seria Monografie i Opracowania, no 551, Wrocław 1991.

11. Książek M., Nowak P., Kivrak S., Rosłon J., Ustinovichius L., “Computer-aided decision-making in construction project development”. Journal of Civil Engineering and Management, Vol. 21, No. 2, 2015, pp. 248-259.

12. Książek, M., Nowak, P., Rosłon, J., Wieczorek, T., "Multicriteria assessment of selected solutions for the building structural walls", 23rd Russian-Polish-Slovak Seminar on Theoretical Foundation of Civil Engineering, TFoCE 2014, Wroclaw, Szklarska Poreba; Poland; 25 August 2014 through 29 August 2014, Procedia Engineering, Vol. 91, 2014, 406-411.

13. Meng, XH, "The role of trust in relationship development and performance improvement", Journal of Civil Engineering and Management Vol.21, No. 7, 2015, pp. 845-853.

14. Michnik J. , „Wielokryterialne metody wspomagania decyzji w procesie innowacji”, Wydawnictwo Uniwersytetu Ekonomicznego w Katowicach, 2013.

15. Nang-Fei P., „Fuzzy AHP approach for selecting the suitable bridge construction method”, Automation in Construction Vol.17, 2008, pp. 958-965.

16. Prusak A., Stefanów P., „AHP - analityczny proces hierarchiczny. Budowa i analiza modeli decyzyjnych krok po kroku", Wydawnictwo C. H. Beck, 2014.

17. Radziszewska-Zielina E., "Analysis of the Impact of the Level of Partnering Relations on the Selected Indexes of Success of Polish Construction Enterprises”, Inzinerine Ekonomika-Engineering Economics, Vol. 21, No. 3, 2010, pp. 324-335.

18. Radziszewska-Zielina E., "Analysis of the partnering relations of Polish, Slovak and Ukrainian construction enterprises", Technological and Economic Development of Economy, Vol. 16, No. 3, 2010, pp. 432-454.

19. Radziszewska-Zielina E., "Fuzzy control of the partnering relations of a construction enterprise", Journal of Civil Engineering and Management, Vol. 17, No. 1, 2011, pp. 5-15.

20. Radziszewska-Zielina E., "Methods for selecting the best partner construction enterprise in terms of partnering relations", Journal of Civil Engineering and Management, Vol. 16, No. 4, 2010, pp. 510-520.

21. Radziszewska-Zielina E., "Studies of the Partner Relations of Construction Companies". LAP LAMBERT Academic Publishing, monograph, 2013.

22. Radziszewska-Zielina E., Szewczyk B., "Controlling partnering relations in construction operations using fuzzy reasoning”, Archives of Civil Engineering, Nr 3(LXI)/2015, pp. 89-104 .

23. Trzaskalik T. (red), „Metody wielokryterialne na polskim rynku finansowym”, Polskie Wydawnictwo Ekonomiczne, Warszawa 200

24. Turskis Z., "Multi-attribute contractors ranking method by applying ordering of feasible alternatives of solutions in terms of preferability technique", Technological and Economic Development of Economy, Vol. 14, No. 2, 2008, pp. 224-239. 
25. Ulubeyli S., Kazaz A., "A Multiple Criteria Decision-Making Approach to the Selection of Concrete Pumps", Journal of Civil Engineering and Management, Vol. 15, No. 4, 2009, 369-376.

Received 16. 12. 2015

Revised 15.01. 2016

\section{LIST OF FIGURES AND TABLES:}

Tab. 1 . Evaluation of construction companies

Tab. 1 . Oceny przedsiębiorstw budowlanych

Tab. 2. The assumed equivalence and veto thresholds and parameter weights

Tab. 2. Przyjęte progi równoważności, weta i wagi.

Tab. 3. The reference system forming the base of the analysis

Tab. 3. Przyjęty system referencyjny

Tab. 4. Outranking indicators $d^{+}\left(a^{i}, r^{j}\right)$ for companies included in the reference system Tab. 4. Wskaźniki przewyższania $d^{+}\left(a^{i}, r^{j}\right)$ dla przedsiębiorstw z systemu referencyjnego

Tab. 5. Outranking indicators $d^{t}\left(a^{i}, r^{j}\right)$ for companies included in the reference system

Tab. 5. Wskaźniki przewyższania $d^{j}\left(a^{i}, r^{j}\right)$ dla przedsiębiorstw z systemu referencyjnego

Tab. 6. Preference structure

Tab. 6. Struktura preferencji

Tab. 7. The position of decision variants - construction companies - in relation to the reference system

Tab. 7. Pozycja wariantów decyzyjnych - przedsiębiorstw budowlanych względem systemu referencyjnego

Tab. 8. A ranking of category S1 companies (overgood) and their $d_{i s}$ degrees of achieving success

Tab. 8. Ranking przedsiębiorstw z kategorii S1 (overgood) i wyznaczone dla nich współczynniki osiągnięcia sukcesu $d_{i s}$

Tab. 9. A ranking of category S2 companies and their $d_{i s}$ degrees of achieving success

Tab. 9. Ranking przedsiębiorstw z kategorii S2 i wyznaczone dla nich współczynniki osiągnięcia sukcesu $d_{i s}$

Tab. 10. A ranking of category N1 companies and their $d_{i N}$ degrees of avoiding failure

Tab. 10. Ranking przedsiębiorstw z kategorii N1 i wyznaczone dla nich współczynniki uniknięcia niepowodzenia $d_{i N}$

Tab. 11. A ranking of category $\mathrm{N} 2$ companies and their $d_{i N}$ degrees of avoiding failure.

Tab. 11. Ranking przedsiębiorstw $\mathrm{z}$ kategorii N2 i wyznaczone dla nich współczynniki uniknięcia niepowodzenia $d_{i N}$

Tab.12. A ranking of B1 category companies and their respective sorting factors

Tab.12. Ranking przedsiębiorstw z kategorii B1 i wyznaczone dla nich wskaźniki sortowania

Tab.13. A ranking of $\mathrm{B} 2$ category companies and their respective sorting factors

Tab.13. Ranking przedsiębiorstw z kategorii B2 i wyznaczone dla nich wskaźniki sortowania 


\section{ZASTOSOWANIE ANALIZY WIELOKRYTERIALNEJ W OCENIE RELACJI PARTNERSKICH I WYBORZE PRZEDSIĘBIORSTWA BUDOWLANEGO DO WSPÓŁPRACY}

Slowa kluczowe: przedsiębiorstwo budowlane, analiza wielokryterialna, relacje partnerskie

\section{STRESZCZENIE:}

Partnerstwo w odróżnieniu od konkurencji charakteryzuje się współpracą a nie rywalizacją. Partnerzy współpracują, dążąc do realizacji przedsięwzięcia budowlanego, które jest ich wspólnym celem, oraz do osiągnięcia obopólnych korzyści.

Istotny wpływ na działalność przedsiębiorstwa budowlanego mają podwykonawcy i generalni wykonawcy. Z tego względu zdecydowano się na opracowanie algorytmu wybierającego najlepsze przedsiębiorstwo budowlane do współpracy podczas realizacji przedsięwzięć budowlanych. Ten algorytm, dla danego przedsiębiorstwa budowlanego, ma wspomagać jego system decyzyjny w zakresie wyboru innego przedsiębiorstwa budowlanego do współpracy partnerskiej. Autorka opracowała i przedstawiła w publikacjach model badawczy relacji partnerskich oraz opracowany algorytm wyboru przedsiębiorstwa budowlanego do współpracy partnerskiej z wykorzystaniem metody ELECTRE III. Wykonała przykład obliczeniowy dla wybranych przedsiębiorstw budowlanych [20]. Na podstawie rankingu zbiorczego metody ELECTRE III wskazała jako najlepsze do współpracy partnerskiej, spośród siedmiu analizowanych, przedsiębiorstwo numer 3 a następnie 7 .

Dobrze jest z naukowego i praktycznego punktu widzenia, jeśli ocena rozważanego problemu jest przeprowadzona za pomocą dwóch różnych metod wielokryterialnych. Jest to sposób na weryfikację otrzymanych wyników. Dlatego też w niniejszym artykule problem oceny relacji partnerskich i wyboru przedsiębiorstwa budowlanego do współpracy, który był analizowany za pomocą metody ELECTRE III w poz. [20] został przeanalizowany za pomocą metody wielokryterialnej BIPROPOL.

„Metoda BIPOLAR jest metodą wielokryterialnego wspomagania podejmowania decyzji, wykorzystywaną do sortowania i rangowania skończonej liczby wariantów decyzyjnych. Porównania wariantów decyzyjnych nie dokonuje się bezpośrednio, lecz z wykorzystaniem podanego przez decydenta dwubiegunowego układu referencyjnego, zawierającego obiekty „dobre” i ,złe” [23, str. 56].

Zaletą zastosowania w rozważanym przypadku metody BIPOLAR jest uzyskanie trzech rankingów. Wybór wariantu decyzyjnego (przedsiębiorstwa budowlanego do współpracy) na postawie rankingu typu S maksymalizuje stopień osiągnięcia sukcesu. Wybór (przedsiębiorstwa budowlanego do współpracy na podstawie rankingu typu N minimalizuje stopień niepowodzenia. Ranking typu B łączy w sobie zarówno stopień osiągnięcia sukcesu jak i stopień uniknięcia niepowodzenia. Wybierając przedsiębiorstwo $\mathrm{z}$ wykorzystaniem rankingu typu $\mathrm{S}$ nie uwzględniamy stopnia niepowodzenia. Może to spowodować wybór wariantów obarczonych dużym ryzykiem niepowodzenia, co w przypadku relacji partnerskich oznacza trudności ze zbudowaniem relacji partnerskich z wybranym przedsiębiorstwem. Wykorzystując do wyboru przedsiębiorstwa budowlanego ranking typu N minimalizujemy stopień niepowodzenia. Oznacza to, że zbudowanie relacji partnerskich z przedsiębiorstwem jest prawie pewne, ale mogą być one na niskim poziomie. Zalety obydwu rankingów łączy w sobie ranking typu B. W podejściu tym do określenia rankingu przedsiębiorstw wykorzystywany jest zarówno stopień osiągnięcia sukcesu jak i uniknięcia porażki. W przypadku relacji partnerskich oznacza to wybór przedsiębiorstwa budowlanego, z którym nawiązanie relacji partnerskich jest relatywnie 
pewnie, a równocześnie można je osiągnąć na dość wysokim poziomie. Decydent może swoją decyzję, w zależności od aktualnej sytuacji i potrzeby, oprzeć na wybranym przez siebie rankingu.

Kolejną zaletą metody BIPOLAR jest możliwość określenia preferencji decydenta na podstawie wskazania obiektów referencyjnych dobrych i złych, co oznacza możliwość pokazania na przykładach, które przedsiębiorstwa budowlane są dla decydenta akceptowalne lub nie akceptowalne. Ten sposób wprowadzania do systemu preferencji decydenta umożliwia zbudowanie samouczącego sytemu (uczy się preferencji decydenta). System taki na podstawie kolejnych zadań (wcześniejszych przedsięwzięć budowlanych) stawianych przez decydenta oraz uwzględniając jego wybory (przedsiębiorstwa do realizacji wcześniejszych przedsięwzięć budowlanych) mógłby samoczynnie modyfikować listy referencyjne obiektów dobrych i złych. Obiekty referencyjne nie muszą być rzeczywistymi przedsiębiorstwami, lecz obiektami stworzonymi na potrzeby analizy.

Metoda BIPOLAR ta składa się z trzech faz:

- -porównania wariantów decyzyjnych z elementami systemu referencyjnego, wyznaczając wskaźniki przewyższania oraz określając strukturę preferencji,

- - określania pozycji każdego wariantu decyzyjnego względem bipolarnego systemu referencyjnego,

- -wnioskowania o relacjach w zbiorze badanych wariantów decyzyjnych, na podstawie wyników uzyskanych w fazach poprzednich.

Celem autorki jest weryfikacja wcześniejszych badań poprzez zastosowanie alternatywnej metody BIPOLAR. Aby wybrać najlepsze przedsiębiorstwo budowlane do współpracy przeanalizowano te same 7 przedsiębiorstw budowlanych co w artykule [20]. Uzyskano taki sam wynik końcowy jak w przypadku zastosowania metody ELECTRE. Te same przedsiębiorstwa okazały się najlepsze.

Opracowane metody wspomagają jedynie system decyzyjny przedsiębiorstwa budowlanego co do wyboru podwykonawcy czyli innego przedsiębiorstwa budowlanego do współpracy partnerskiej. Ostateczną decyzję zawsze musi podjąć decydent samodzielnie. 